\title{
Filling the Silent Void: Genetic Therapies for Hearing Impairment
}

\author{
Joel Sng and Thomas Lufkin \\ Stem Cell and Developmental Biology, Genome Institute of Singapore, 60 Biopolis Street, Singapore 138672 \\ Correspondence should be addressed to Thomas Lufkin, lufkin@gis.a-star.edu.sg
}

Received 12 April 2012; Revised 27 September 2012; Accepted 4 November 2012

Academic Editor: Tomaso Patarnello

Copyright ( $\odot 2012$ J. Sng and T. Lufkin. This is an open access article distributed under the Creative Commons Attribution License, which permits unrestricted use, distribution, and reproduction in any medium, provided the original work is properly cited.

\begin{abstract}
The inner ear cytoarchitecture forms one of the most intricate and delicate organs in the human body and is vulnerable to the effects of genetic disorders, aging, and environmental damage. Owing to the inability of the mammalian cochlea to regenerate sensory hair cells, the loss of hair cells is a leading cause of deafness in humans. Millions of individuals worldwide are affected by the emotionally and financially devastating effects of hearing impairment (HI). This paper provides a brief introduction into the key role of genes regulating inner ear development and function. Potential future therapies that leverage on an improved understanding of these molecular pathways are also described in detail.
\end{abstract}

\section{Introduction}

The human ear is a highly complex instrument that is comprised of three main sections: the outer ear, the middle ear, and the inner ear. While many surgical remedies exist for the treatment of hearing loss stemming from dysfunction of the outer and middle ear, few effective remedies have been developed for the treatment of hearing impairment resulting from inner ear disorders. The inner ear is comprised of two main components, the auditory system which receives the amplified mechanical vibrations transmitted from the middle ear and the vestibular system which is responsible for maintaining balance. The auditory system of the inner ear consists of the cochlea which contains three fluid filled spaces, the scala vestibule, scala media, and scala tympani [1]. Mechanical vibrations from the middle ear are propagated through these spaces and are detected by the organ of Corti which is located on the basilar membrane of the scala media. The organ of Corti is a complex structure containing hair cells and supporting pillar and Deiters cells. Hair cells located in the organ of Corti generate action potentials in response to perturbations which are transmitted to the auditory cortex via the cochlear nerve [2].

Hearing loss is classified according to the region of the ear affected. Conductive hearing loss is usually diagnosed as defects in the outer and middle ear that prevent sound from being transmitted to the cochlea while sensorineural hearing loss is usually diagnosed as dysfunction of the inner ear, cochlear nerve, or auditory cortex. Many studies have demonstrated that the impact of inherited genetic mutations on hearing impairment (HI) is especially significant. Various mutations in a single gene can cause either syndromic or nonsyndromic hereditary hearing loss (HHL) and result in $\mathrm{HI}$ at different stages in life and over seventy chromosomal genes. Two mitochondrial genes, which harbour seven different mutations, have been linked to nonsyndromic HHL alone [3]. HHL also is the main cause of early-onset HI with more than $60 \%$ of such affected individuals suffering from HHL [4], with single-gene mutations probably accounting for at least half the cases of childhood deafness $[5,6]$. In addition, about ten percent of the adult population is affected by $\mathrm{HI}$ [7] and age related $\mathrm{HI}$ is one of the most prevalent chronic conditions with $25-40 \%$ of the population aged 65 or older affected [8]. As the global population ages, research on developing preventive medicine and therapies for $\mathrm{HI}$ is increasingly essential. A majority of these patients suffer from hearing loss owing to damage to hair cells in the cochlea [9] and as these cells do not regenerate spontaneously in mammals, the loss of hearing is often permanent [10, 11]. Hence understanding the link between genetics, HI, 
hair cells, and the highly differentiated supporting cells surrounding them, remains a prerequisite to developing effective regenerative therapies.

\section{The Role of Genetics}

A concerted effort of many genes is required for the development, maintenance, and proper functioning of the inner ear and a comprehensive mastery of these molecular pathways is essential for understanding how inner ear progenitor cells progress through states of developmental competence, coordinated cell cycle exit, and differentiation to form and maintain the cochlea's complex cytoarchitecture. To this end, animals have served as attractive models of human HI owing to the difficulty of observing key developmental pathways and the progression of dysfunction in the human cochlea $[4,12,13]$ (Table 1). The homeobox gene family is one of the major groups of genes that play an important role in inner ear development and has been extensively studied in various animal models. Characterized by a $180 \mathrm{bp}$ homeodomain, these genes encode for essential transcription factors that can recognize and bind to specific DNA motifs and act as key regulators of morphogenesis [14]. Many members of the homeobox gene family have been implicated in vertebrate inner ear formation including the Pax paired-homeobox gene family, Otx homeobox gene family, Gastrulation brain homeobox (Gbx) gene family, Msx homeobox gene family, $D l x$ homeobox gene family, and Hmx homeobox gene family (for review see [15]).

Other genes play equally important roles in ensuring correct cellular patterning in the inner ear. The Notch signaling pathway and its ligands DLL1 and JAG2 form a highly conserved cell signaling system essential for influencing the fate of progenitor cells during inner ear formation and lateral-inhibition mediated differentiation of hair cells [48]. High levels of Notch signaling promote Sox2 expression [52] which may encourage the initial proliferation of inner ear stem cells to form a prosensory zone of nonproliferating cells expressing inhibitory p $27^{\text {Kip } 1}$ along the length of the cochlea. This expression of Notch1 also inhibits premature hair cell differentiation. A combination of the Notch-Hes 1 pathway and Fibroblast growth factor $(F g f)$ signaling is also essential for activating various transcription factors required for the further specification in the prosensory domain of the inner ear potentially by the transcriptional downregulation of p $27^{\text {Kipl }}[50,53,54]$. Later reduction of Notch signaling then increases Atoh1 (also known as Math1) expression which induces the formation of hair cells [55]. Initially differentiated inner hair cells can then direct the secondary differentiation and placement of neighboring supporting cells such as the pillar cells. Inner hair cells express Fgf8 and produce Fgf8 which is a high affinity ligand of Fgf receptor 3 found on neighboring progenitor cells $[56,57]$. Binding of Fgf8 to Fgfr3 induces the differentiation of these neighboring cells into pillar cells forming the distinct cellular patterns in the cochlea $[40,58]$. The production of Fgf8 in hair cells also maintains the expression of Hey 2 in surrounding pillar cells which prevents them from transdifferentiating into hair cells and creates a clean distribution between pillar cells and Deiters' cells by inhibitory interactions between Hey 2 and Hes5, preserving the complex patterned structure of the cochlear [47]. Hence Notch signaling plays an essential role in regulating the expression of transcription factors and aids in the differentiation and maintenance of inner ear stem cells to form the key cell types in the cochlea.

The retinoblastoma $(\mathrm{Rb})$ family of cell cycle regulators such as $R b 1$ (pRb), Rbl1 (p107), and Rbl2 (p130) also plays an essential role in regulating the proliferation of supporting cells and hair cells $[23,27,59]$. In particular, $R b 1$ (and its encoded protein $\mathrm{pRb}$ ) plays an essential role in hair cell quiescence and $\mathrm{pRb}$ inactivation results in cell cycle reentry and the abnormal proliferation of hair cells [24-26]. pRb functions by interacting with and inhibiting the activity of E2F transcription factors such as E2F1 $[38,39]$. However while the loss of $\mathrm{pRb}$ is most significant during the early phases of inner ear development and leads to increased proliferation of hair and supporting cells, $\mathrm{Rb} 1$ deletion alone in the adult mouse is insufficient to reinitiate proliferation in the inner ear suggesting that other regulators are able to compensate for the loss of Rb1 [23].

The above description of the Notch1 signaling pathway, $\mathrm{Rb}$ cell cycle regulators, and homeobox genes only provides an abridged version of the complex web of gene regulatory networks necessary for transforming a mass of undifferentiated stem cells into the complex cytoarchitecture of the inner ear. There is substantial evidence that the Myosin gene family plays a critical role in the function of inner ear hair cells. Myosins are a superfamily of ATP-dependent motor proteins which can act as force sensors to detect auditory stimuli [60] and are divided into at least twenty-four classes [61]. Various myosins play significant roles in hearing. Myosin genes implicated in human hearing loss include MYO1A, MYO6, MYO7A, and MYO15. The myosin-I isoform (myolc) has been shown to sensitize transduction channels and is an essential component of the hair cell's adaptation-motor complex $[62,63]$ in mice. Mutations in MYO1A, a cochlear expressed gene located in the DFNA48 locus, have also been identified as a contributor to autosomal dominant hearing loss in humans [28]. Other genes of interest include Forkhead genes like Foxg1 which can cooperate with Fgf10 and interact with the Notch/Hes signaling system to regulate the size of sensory epithelia [43], and basic helix-loop-helix genes like $\mathrm{Ngn} 1$ that promote neurogenesis and maintain progenitor cell populations [49] (Table 1).

\section{Developing Therapies for $\mathbf{H I}$}

Although it is relatively easy to diagnose HI, it is much harder to determine its underlying causes owing to their large heterogeneity ranging from complex genetic disorders, environmental effects, drug-side effects, infection, and other unknown causes. In addition the only available treatment options are limited to hearing aids and cochlear implants which are not equally effective in all patients owing to the complex pathogenesis of $\mathrm{HI}$ and different degrees of tissue damage. There are also no treatments available to arrest or 
TABle 1

\begin{tabular}{|c|c|c|}
\hline \multicolumn{3}{|c|}{ Genes that regulate the development of the ear } \\
\hline Gene & Description & References \\
\hline \multicolumn{3}{|c|}{ Homeobox gene superfamily } \\
\hline $\operatorname{Pax}$ & $\begin{array}{l}\text { Pax } 2 \text { required for organ of Corti formation, expression of } \operatorname{Pax} 5 \text { can compensate for loss of } \operatorname{Pax} 2 \\
\text { expression. }\end{array}$ & {$[16]$} \\
\hline Otx & $\begin{array}{l}\text { Otx } 1 \text { required for saccule and utricle segregation and formation of the horizontal canal. Otx2 } \\
\text { required for segregation of inner ear and trigeminal progenitors. }\end{array}$ & {$[17,18]$} \\
\hline$G b x$ & Gbx2 required in posterior otic placode formation. & {$[18]$} \\
\hline$M s x$ & $\begin{array}{l}\text { Msxl expressed in the preotic placodal region, possibly a regulator of neural development. Plays } \\
\text { role in regulating epithelial-mesenchymal interaction. }\end{array}$ & {$[15,19,20]$} \\
\hline$D l x$ & $\begin{array}{l}\text { Dlx5 and Dlx6 required for formation of semicircular ducts, saccule, and utricle. Inhibits Pax2 } \\
\text { and activates } G b \times 2 \text { expression. }\end{array}$ & {$[21]$} \\
\hline$H m x$ & $\begin{array}{l}H m \times 2 \text { and } H m \times 3 \text { coexpressed in the dorsolateral otic epithelium, controls cell proliferation, and } \\
\text { regulates morphology of inner ear. }\end{array}$ & {$[22]$} \\
\hline \multicolumn{3}{|c|}{ Retinoblastoma ( $\mathrm{Rb})$ family } \\
\hline$R b 1$ & $\begin{array}{l}\text { Cell cycle regulator ( } \mathrm{G} \text { to } \mathrm{S} \text { phase transition), required for hair cell quiescence. Deletion of } R b 1 \\
\text { induces proliferation and differentiation of hair cells. However deletion of } R b 1 \text { in adult mice is } \\
\text { insufficient for inducing hair cell proliferation. }\end{array}$ & {$[23-26]$} \\
\hline Rbll & Cell cycle regulator ( $G$ to $S$ phase transition). & {$[24]$} \\
\hline$R b l 2$ & $\begin{array}{l}\text { Cell cycle regulator ( } G \text { to } S \text { phase transition). Deletion results in additional rows of hair and } \\
\text { supporting cells. }\end{array}$ & {$[27]$} \\
\hline \multicolumn{3}{|c|}{ Myosin superfamily } \\
\hline MYO1A & $\begin{array}{l}\text { Located within DFNA48 locus, expressed within cochlear, mutation results in sensorineural } \\
\text { hearing impairment. Myolb located at apical surface of supporting cells, Myolc concentrated at } \\
\text { hair cell stereocilia, Myole located at hair cells of auditory epithelia. }\end{array}$ & {$[28,29]$} \\
\hline MYO6 & $\begin{array}{l}\text { Required for the structural maintenance of hair cell stereocilia, mutation leads to autosomal } \\
\text { dominant hearing loss. }\end{array}$ & {$[30,31]$} \\
\hline MYO7A & $\begin{array}{l}\text { Required for inner ear endocytosis, mutations can result in Usher syndrome or nonsyndromic } \\
\text { deafness. }\end{array}$ & {$[32,33]$} \\
\hline MYO15 & $\begin{array}{l}\text { Required for development and elongation of hair cell stereocilia, mutation associated with } \\
\text { hearing impairment. }\end{array}$ & {$[34,35]$} \\
\hline \multicolumn{3}{|c|}{ Other genes } \\
\hline Atoh1 (Math1) & $\begin{array}{l}\text { Helix-loop-helix transcription factor required for the development, differentiation, and } \\
\text { regeneration of functional hair cells. }\end{array}$ & {$[36,37]$} \\
\hline E2F1 & Transcription factor involved in cell cycle regulation. Mediates $\mathrm{pRb}(R b 1)$ function. & {$[23,38,39]$} \\
\hline$F g f$ & $\begin{array}{l}\text { Expression of } F g f 3 \text { and } F g f 10 \text { required for } D l x 5 \text { and } D l x 6 \text { expression. } F g f 10 \text { required for posterior } \\
\text { canal and hair cell cilia formation. } F g f 8 \text { binds to } F g f r 3 \text { and is involved in pillar cell formation and } \\
\text { cellular patterning in cochlea. }\end{array}$ & {$[40-42]$} \\
\hline Foxg1 & $\begin{array}{l}\text { Required for inner ear sensory cristae formation, regulates sensory fate and embryonic } \\
\text { neurosensory development. Mutation results in a shortened cochlea and loss of crista neurons. }\end{array}$ & [43-45] \\
\hline Hes1 & Controls patterning of inner hair cells in organ of Corti, functions with Hey2. & {$[46]$} \\
\hline Hes5 & Controls patterning of outer hair cells in organ of Corti, functions with Hey2. & {$[46]$} \\
\hline Hey 2 & $\begin{array}{l}\text { Activated by Fgf, prevents pillar cells from differentiating into hair cells. Controls patterning in } \\
\text { organ of Corti, functions with Hes } 1 \text { and Hes5. }\end{array}$ & {$[46,47]$} \\
\hline Notch & Regulates hair cell fate and patterning in cochlea, regulated by Notch ligands DLL1 and JAG2. & {$[48]$} \\
\hline $\operatorname{Ngn1}$ & $\begin{array}{l}\text { Regulates transition from neurogenesis to sensory cell development. Process cross-regulated by } \\
\text { both Ngn1 and Atoh1. }\end{array}$ & {$[49]$} \\
\hline$p 27^{\text {Kipl }}$ & $\begin{array}{l}\text { Regulated by Notch-Hes1 signalling pathway. Cyclin-dependent kinase cell cycle inhibitor. Loss of } \\
p 27^{\text {Kipl }} \text { initiates cellular proliferation in organ of Corti. }\end{array}$ & {$[50,51]$} \\
\hline Sox 2 & $\begin{array}{l}\text { Promoted by Notch1 signalling, regulates hair cell differentiation and proliferation. Mutation } \\
\text { results in sensorineural hearing impairment. }\end{array}$ & {$[52]$} \\
\hline
\end{tabular}


reverse the progression of $\mathrm{HI}$. In the light of these limitations, there has been intense interest in developing new approaches for treating HI which include developing gene therapies, stem cell therapies, and drugs to induce the regeneration of the sensory epithelia in the inner ear. To overcome the difficulties of studying degenerative changes in the human cochlea, several animal models that replicate the symptoms of HI have been developed. These include the development of in utero gene transfer mouse models [64], for evaluating the effectiveness of potential gene therapies in reversing human HI $[4,65]$.

Accurate diagnosis of the underlying cause of $\mathrm{HI}$ on a molecular level will be essential for the design of personalized gene therapies since many different gene mutations can cause similar HI phenotypes. The search for new targets for human HI gene therapy is hindered by the lack of tools to study inner ear function in vivo as well as cell lines which accurately model cochlea function. Hence mice and guinea pigs remain popular model systems of human HI owing to their evolutionary closeness and the availability of many hearing-impaired mutant lines. Gene therapy which focuses on the regeneration of damaged hair cells by restoring the expression of Atoh1 (or Math1) is commonly seen as one of the more promising candidate cures for HI. Atoh1 encodes for a helix-loop-helix transcription factor which is required for the differentiation of hair cells in the vertebrate inner ear and targeted disruption of Atoh1 prevents the development of auditory and vestibular hair cells [66]. Targeted expression of Atoh1 in the organ of Corti is also essential for normal hair cell function and maintenance. Delayed Atoh1 deletion in conditional knockout mice causes the loss of inner hair cells and a significant amount of outer hair cells three weeks after delivery [36]. Reexpression of Atoh1 by in vivo adenovirus mediated gene transfer has been shown to induce the regeneration of hair cells, encourage neuronal growth towards these newly differentiated cells, and reverse HI in adult Guinea pigs [37, 67]. These cells have also been characterized by patch clamping and been shown to have functional mechanotransduction [64]. Hence gene therapy involving Atoh1 may potentially be a viable method for restoring the damaged auditory neuroepithelium. However, reexpression of Atoh1 alone may not be sufficient to improve hearing thresholds if endogenous progenitor cells are absent [68]. The effectiveness of direct transdifferentiation of supporting cells to hair cells may also be limiting because of the loss of supporting cells that have equally important roles, insufficient numbers of transdifferentiated hair cells generated, and the nonideal positioning of newly transdifferentiated hair cells. Hence the complex multifactor nature of regeneration requires combinatorial gene therapies that simultaneously guide proliferation, transdifferentiation, and positioning of progenitor cells to restore the cytoarchitecture structure and function of the organ of Corti. For example, the overexpression of the cell cycle enhancement gene SKP2 can induce proliferation of nonsensory cells which can then transdifferentiate in the presence of Atoh1 [69]. This combined overexpression of both $S k p 2$ and Atoh1 induces formation of a greater number of hair cells compared with Atoh 1 overexpression alone and indicates that multiple gene therapies may provide more effective solutions for reversing the effects of HI.

For targeted gene therapy to be successful, the identification of progenitor cells for hair cells and the elucidation of molecular pathways that regulate their maintenance, proliferation, and specialization are essential. These cells are necessary as they have the potential to differentiate or transdifferentiate into hair cells. Identification of gene targets that maintain and regulate these cells will be essential for reversing the symptoms of HI. Potential progenitors of hair cells may be found in the dorsal epithelium of the cochlear canal [70] and could be induced to differentiate into functional hair cells. Pluripotent stem cells have also been discovered in the adult utricular sensory epithelium and are able to form cells of all three germ layers, including hair cells [71]. Supporting cells could also be a potential target in future gene therapies as they serve as a natural source of new hair cells in nonmammalian vertebrates [72-74] and have also demonstrated limited capacity for transdifferentiation in some mammalian studies $[75,76]$.

Gene therapies could be combined with cochlear implants to develop novel cures for HI. While spiral ganglion density in most patients who receive cochlear implants may initially be sufficient to produce satisfactory results, the long term effectiveness of cochlear implants which operate by exciting spiral ganglion neurons (SGN) for patients with profound sensorineural hearing loss is limited because of the potential degradation of SGNs [77, 78]. The loss of hair cells and supporting cells which produce neurotrophins like NT-3 [79] and maintain the SGN via the neuregulin (NRG)-erbB receptor signaling pathway [80] contributes to the degradation of the SGN and neural death, however the continuous inoculation of neurotrophins to the cochlea can halt SGN degradation in deaf guinea pigs [81, 82]. Fibroblast growth factors (FGFs) are also essential for SGN maintenance [83] and combined treatment with FGF and neurotrophins may prevent secondary deterioration of SGNs [84]. Hence gene therapy stimulating the in vivo production of neurotrophins and fibroblast growth factors combined with electrical stimulation from cochlear implants could encourage extended survival of SGNs by inducing long-term in vivo production of essential growth factors and improve the long-term therapeutic benefits of cochlear implants $[85,86]$. Therapies which maintain neurotrophin producing supporting cells populations would also have similar effect [87].

Therapies involving the transplantation of exogenous stem cells and other multipotent cells also provide a possible solution for the reconstitution of normal cochlea function if endogenous progenitor cells are absent. Stem cells have the capacity for self-renewal and are able to form specialized cell types including hair cells, spiral ganglion neurons, and their progenitors [88] for restoring normal cochlea function. Many studies have demonstrated the innate ability of transplanted cells to survive and differentiate. For example, the introduction of bone marrow stromal cells into the cochlea of chinchillas has resulted in increased expression of neuronal and glial cell markers in grafted cells suggesting their potential as transplants for restoring cochlea 
function [89]. Previous studies have also proven that fetal mouse and guinea pig spinal ganglions can survive grafting into the cochlea of their adult counterparts and that the survival of these implants is increased by treatment with neurotrophic factors like ciliary neurotrophic factor and brain-derived neurotrophic factor $[90,91]$. The combined treatment of implanted cells with neurotrophic growth factor and chronic electrical stimulation also stimulates increased neurite outgrowth to the spiral ganglion region [92]. In addition, xenografts of the spinal ganglion neurons, embryonic stem cells, and adult neural stem cells (in rat and guinea pig) can survive, migrate, and differentiate successfully in the relatively immunoprivileged nature of the peripheral and central nervous system [93]. More recently, the implantation of hESC-derived neurons and hair cells into auditory neuropathic gerbils led to the successful recovery of auditory neuron functionality and the restoration of auditory evoked response thresholds [94]. These studies demonstrate the potential of transplants to restore normal cochlea function and form neuronal connections between the cochlea and the central nervous system. In addition the possibility of developing combinational therapies involving stem cell transplants, cochlear implants, gene therapy, and drugs could also lead to an effective therapeutic solution for a wider range of hearing impaired patients.

The development of novel techniques for efficient delivery of emerging therapies continues to be an essential component of a successful therapy. Advances in this area have led to the refinement of procedures for stem cell transplant, gene therapy, and controlled local drug delivery. Potential stem and progenitor cell transplants could be performed surgically via the basal turn of the cochlea or through implantable delivery systems (for review see [95]). Successful stem cell transplantation will also involve the use of either a microinjector or an osmotic pump coupled with a catheter system enabling multiple implantation of small volumes of cells at specific locations within the inner ear $[96,97]$. While the various techniques developed allow the implantation of therapeutic cells into various sites of the inner ear (scala media, scala tympani, perilymphatic space, and modiolus) key limitations preventing the utilization of existing techniques in successful therapies include the fact that transplanted cells often fail to integrate appropriately with epithelium architecture and invasive surgical procedures may result in the loss of endolymph from the scala media resulting in the disruption of cochlear function [95, 98].

The effectiveness of various viral and nonviral vectors has been investigated for inner ear gene therapy. For example, bovine adeno-associated virus vectors (BAV) inoculated to the scala tympani resulted in successful transgene expression at the membranous labyrinth [99]. Supporting in vitro research also indicates that BAV can be successfully utilized for restoring gap junction coupling and connexin protein expression [100]. The microinjection of adenovirus based vectors near the fenestra cochleare also resulted in sustained protein expression for approximately four weeks [101]. Recent studies have also demonstrated the potential of nonviral vectors in gene therapy. Hyperbranched polylysine nanoparticles administered to the round window of rats were able to integrate efficiently into spiral ganglion cells and organ of Corti [102]. Nerve Growth Factor-derived peptide functionalized nanoparticles may also be a viable tool for targeted drug delivery into the inner ear [103]. Similarly biodegreadable CGP-hydrogels, liposome, and polymersome nanoparticles can be synthesized and injected onto the round window niche for controlled delivery of drugs to the inner ear $[104,105]$. The increasing availability of specialized instruments such as microendoscopes, cochlear implant associated delivery systems, and reciprocating drug delivery systems presents an expanding variety of options for drug delivery and increases the potential that similar methods could also be utilized for gene therapy and progenitor cell transplants [106-108].

\section{Conclusion}

Animal models of human HI remain essential for investigating potential future therapies that leverage on an improved understanding of the molecular pathways that regulate proliferation, differentiation, and structure in the inner ear. To cure HI due to dysfunction of the inner ear, therapies that induce functional restoration of the highly complex cochlea cytoarchitecture must be developed. Future combinational therapies involving various permutations of progenitor cell transplantation, cochlear implants, targeted gene therapy, and drugs may provide interesting therapeutic results and lead the development of effective therapies for a wider range of HI patients.

\section{References}

[1] Y. Raphael and R. A. Altschuler, "Structure and innervation of the cochlea," Brain Research Bulletin, vol. 60, no. 5-6, pp. 397-422, 2003.

[2] M. Ospeck, "Fast negative feedback enables Mammalian auditory nerve fibers to encode a wide dynamic range of sound intensities," PLoS ONE, vol. 7, no. 3, Article ID e32384, 2012.

[3] G. A. S. VAN CAMP, R.J.H., Hereditary Hearing Loss, 2012, http://hereditaryhearingloss.org/.

[4] L. M. Friedman, A. A. Dror, and K. B. Avraham, "Mouse models to study inner ear development and hereditary hearing loss," International Journal of Developmental Biology, vol. 51, no. 6-7, pp. 609-631, 2007.

[5] A. L. DeStefano, G. A. Gates, N. Heard-Costa, R. H. Myers, and C. T. Baldwin, "Genomewide linkage analysis to presbycusis in the Framingham Heart Study," Archives of Otolaryngology, vol. 129, no. 3, pp. 285-289, 2003.

[6] K. P. Steel and C. J. Kros, "A genetic approach to understanding auditory function," Nature Genetics, vol. 27, no. 2, pp. 143-149, 2001.

[7] Disorders, NIoDaC, 2004.

[8] B. Yueh, N. Shapiro, C. H. MacLean, and P. G. Shekelle, "Screening and management of adult hearing loss in primary care: scientific review," Journal of the American Medical Association, vol. 289, no. 15, pp. 1976-1985, 2003.

[9] K. Oshima, S. Suchert, N. H. Blevins, and S. Heller, "Curing hearing loss: patient expectations, health care practitioners, 
and basic science," Journal of Communication Disorders, vol. 43, no. 4, pp. 311-318, 2010.

[10] S. Chardin, R. Romand, H. Staecker et al., "Regeneration and mammalian auditory hair cells," Science, vol. 267, no. 5198, pp. 707-711, 1995.

[11] D. W. Roberson and E. W. Rubel, "Cell division in the gerbil cochlea after acoustic trauma," American Journal of Otology, vol. 15, no. 1, pp. 28-34, 1994.

[12] S. Braun, Q. Ye, A. Radeloff, J. Kiefer, W. Gstoettner, and J. Tillein, "Protection of inner ear function after cochlear implantation: compound action potential measurements after local application of glucocorticoids in the guinea pig cochlea," ORL, vol. 73, no. 4, pp. 219-228, 2011.

[13] G. S. Giebink, "Otitis media: the chinchilla model," Microbial Drug Resistance, vol. 5, no. 1, pp. 57-72, 1999.

[14] A. Dorn, M. Affolter, W. J. Gehring, and W. Leupin, "Homeodomain proteins in development and therapy," Pharmacology and Therapeutics, vol. 61, no. 1-2, pp. 155-184, 1994.

[15] S. Chatterjee, P. Kraus, and T. Lufkin, "A symphony of inner ear developmental control genes," BMC Genetics, vol. 11, article 68, 2010.

[16] M. Bouchard, D. De Caprona, M. Busslinger, P. Xu, and B. Fritzsch, "Pax2 and Pax8 cooperate in mouse inner ear morphogenesis and innervation," BMC Developmental Biology, vol. 10, article 89, 2010.

[17] K. W. Beisel, Y. Wang-Lundberg, A. Maklad, and B. Fritzsch, "Development and evolution of the vestibular sensory apparatus of the mammalian ear," Journal of Vestibular Research, vol. 15, no. 5-6, pp. 225-241, 2005.

[18] B. Steventon, R. Mayor, and A. Streit, "Mutual repression between Gbx2 and Otx2 in sensory placodes reveals a general mechanism for ectodermal patterning," Developmental Biology, vol. 367, no. 1, pp. 55-65, 2012.

[19] A. Streit, "Extensive cell movements accompany formation of the otic placode," Developmental Biology, vol. 249, no. 2, pp. 237-254, 2002.

[20] I. Satokata and R. Maas, "Msx1 deficient mice exhibit cleft palate and abnormalities of craniofacial and tooth development," Nature Genetics, vol. 6, no. 4, pp. 348-356, 1994.

[21] R. F. Robledo and T. Lufkin, "Dlx5 and Dlx6 homeobox genes are required for specification of the mammalian vestibular apparatus," Genesis, vol. 44, no. 9, pp. 425-437, 2006.

[22] W. Wang and T. Lufkin, "Hmx homeobox gene function in inner ear and nervous system cell-type specification and development," Experimental Cell Research, vol. 306, no. 2, pp. 373-379, 2005.

[23] M. Huang, C. Sage, Y. Tang et al., "Overlapping and distinct $\mathrm{pRb}$ pathways in the mammalian auditory and vestibular organs," Cell Cycle, vol. 10, no. 2, pp. 337-351, 2011.

[24] Y. Yu, T. Weber, T. Yamashita et al., "In vivo proliferation of postmitotic cochlear supporting cells by acute ablation of the retinoblastoma protein in neonatal mice," Journal of Neuroscience, vol. 30, no. 17, pp. 5927-5936, 2010.

[25] J. Mantela, Z. Jiang, J. Ylikoski, B. Fritzsch, E. Zacksenhaus, and U. Pirvola, "The retinoblastoma gene pathway regulates the postmitotic state of hair cells of the mouse inner ear," Development, vol. 132, no. 10, pp. 2377-2388, 2005.

[26] C. Sage, M. Huang, K. Karimi et al., "Proliferation of functional hair cells in vivo in the absence of the retinoblastoma protein," Science, vol. 307, no. 5712, pp. 1114-1118, 2005.
[27] S. M. Rocha-Sanchez, L. R. Scheetz, M. Contreras et al., "Mature mice lacking Rbl2/p130 gene have supernumerary inner ear hair cells and supporting cells," Journal of Neuroscience, vol. 31, no. 24, pp. 8883-8893, 2011.

[28] F. Donaudy, A. Ferrara, L. Esposito et al., "Multiple mutations of MYO1A, a cochlear-expressed gene, in sensorineural hearing loss," American Journal of Human Genetics, vol. 72, no. 6, pp. 1571-1577, 2003.

[29] R. A. Dumont, Y. D. Zhao, J. R. Holt, M. Bähler, and P. G. Gillespie, "Myosin-I isozymes in neonatal rodent auditory and vestibular epithelia," Journal of the Association for Research in Otolaryngology, vol. 3, no. 4, pp. 375-389, 2002.

[30] R. Hertzano, E. Shalit, A. K. Rzadzinska et al., "A Myo6 mutation destroys coordination between the myosin heads, revealing new functions of myosin VI in the stereocilia of mammalian inner ear hair cells," PLoS Genetics, vol. 4, no. 10, Article ID e1000207, 2008.

[31] N. Hilgert, V. Topsakal, J. van Dinther, E. Offeciers, P. Van de Heyning, and G. Van Camp, "A splice-site mutation and overexpression of MYO6 cause a similar phenotype in two families with autosomal dominant hearing loss," European Journal of Human Genetics, vol. 16, no. 5, pp. 593-602, 2008.

[32] S. Riazuddin, S. Nazli, Z. M. Ahmed et al., "Mutation spectrum of MYO7A and evaluation of a novel nonsyndromic deafness DFNB2 allele with residual function," Human Mutation, vol. 29, no. 4, pp. 502-511, 2008.

[33] T. B. Friedman, J. R. Sellers, and K. B. Avraham, "Unconventional myosins and the genetics of hearing loss," American Journal of Medical Genetics, vol. 89, no. 3, pp. 147-157, 1999.

[34] U. Manor, A. Disanza, M. Grati et al., "Regulation of stereocilia length by myosin XVa and whirlin depends on the actin-regulatory protein Eps8," Current Biology, vol. 21, no. 2, pp. 167-172, 2011.

[35] N. Nal, Z. M. Ahmed, E. Erkal et al., "Mutational spectrum of MYO15A: the large N-terminal extension of myosin XVA is required for hearing," Human Mutation, vol. 28, no. 10, pp. 1014-1019, 2007.

[36] N. Pan, I. Jahan, J. Kersigo, J. S. Duncan, B. Kopecky, and B. Fritzsch, "A novel Atoh1, "self-terminating" mouse model reveals the necessity of proper Atoh1 level and duration for hair cell differentiation and viability," PLoS ONE, vol. 7, no. 1, Article ID e30358, 2012.

[37] M. Izumikawa, R. Minoda, K. Kawamoto et al., "Auditory hair cell replacement and hearing improvement by Atoh1 gene therapy in deaf mammals," Nature Medicine, vol. 11, no. 3, pp. 271-276, 2005.

[38] D. G. Johnson, J. K. Schwarz, W. D. Cress, and J. R. Nevins, "Expression of transcription factor E2F1 induces quiescent cells to enter S phase," Nature, vol. 365, no. 6444, pp. 349352, 1993.

[39] D. G. Johnson, W. D. Cress, L. Jakoi, and J. R. Nevins, "Oncogenic capacity of the E2F1 gene," Proceedings of the National Academy of Sciences of the United States of America, vol. 91, no. 26, pp. 12823-12827, 1994.

[40] B. E. Jacques, M. E. Montcouquiol, E. M. Layman, M. Lewandoski, and M. W. Kelley, "Fgf8 induces pillar cell fate and regulates cellular patterning in the mammalian cochlea," Development, vol. 134, no. 16, pp. 3021-3029, 2007.

[41] D. A. Frenz, W. Liu, A. Cvekl et al., "Retinoid signaling in inner ear development: a "Goldilocks" phenomenon," 
American Journal of Medical Genetics, Part A, vol. 152, no. 12, pp. 2947-2961, 2010.

[42] S. Pauley, T. J. Wright, U. Pirvola, D. Ornitz, K. Beisel, and B. Fritzsch, "Expression and function of FGF10 in mammalian inner ear development," Developmental Dynamics, vol. 227, no. 2, pp. 203-215, 2003.

[43] S. Pauley, E. Lai, and B. Fritzsch, "Foxg1 is required for morphogenesis and histogenesis of the mammalian inner ear," Developmental Dynamics, vol. 235, no. 9, pp. 2470-2482, 2006.

[44] H. H. Chan, A. Simeone, E. Lai, and D. K. Wu, "Foxg1 is required for proper separation and formation of sensory cristae during inner ear development," Developmental Dynamics, vol. 238, no. 11, pp. 2725-2734, 2009.

[45] J. Kersigo, A. D'Angelo, B. D. Gray, G. A. Soukup, and B. Fritzsch, "The role of sensory organs and the forebrain for the development of the craniofacial shape as revealed by Foxg1cre-mediated microRNA loss," Genesis, vol. 49, no. 4, pp. 326-341, 2011.

[46] S. Li, S. Mark, K. Radde-Gallwitz, R. Schlisner, M. T. Chin, and P. Chen, "Hey2 functions in parallel with Hes1 and Hes5 for mammalian auditory sensory organ development," BMC Developmental Biology, vol. 8, article 20, 2008.

[47] A. Doetzlhofer, M. L. Basch, T. Ohyama, M. Gessler, A. K. Groves, and N. Segil, "Hey2 regulation by FGF provides a notch-independent mechanism for maintaining pillar cell fate in the organ of Corti," Developmental Cell, vol. 16, no. 1, pp. 58-69, 2009.

[48] A. E. Kiernan, R. Cordes, R. Kopan, A. Gossler, and T. Gridley, "The Notch ligands DLL1 and JAG2 act synergistically to regulate hair cell development in the mammalian inner ear," Development, vol. 132, no. 19, pp. 4353-4362, 2005.

[49] S. Raft, E. J. Koundakjian, H. Quinones et al., "Crossregulation of Ngn1 and Math1 coordinates the production of neurons and sensory hair cells during inner ear development," Development, vol. 134, no. 24, pp. 4405-4415, 2007.

[50] J. Murata, T. Ohtsuka, A. Tokunaga et al., "Notch-Hes1 pathway contributes to the cochlear prosensory formation potentially through the transcriptional down-regulation of p27Kip1," Journal of Neuroscience Research, vol. 87, no. 16, pp. 3521-3534, 2009.

[51] E. C. Oesterle, W. M. Chien, S. Campbell, P. Nellimarla, and M. L. Fero, "p27Kip1 is required to maintain proliferative quiescence in the adult cochlea and pituitary," Cell Cycle, vol. 10, no. 8, pp. 1237-1248, 2011.

[52] A. Dabdoub, C. Puligilla, J. M. Jones et al., "Sox2 signaling in prosensory domain specification and subsequent hair cell differentiation in the developing cochlea," Proceedings of the National Academy of Sciences of the United States of America, vol. 105, no. 47, pp. 18395-18401, 2008.

[53] M. W. Kelley, "Cellular commitment and differentiation in the organ of Corti," International Journal of Developmental Biology, vol. 51, no. 6-7, pp. 571-583, 2007.

[54] G. Abelló and B. Alsina, "Establishment of a proneural field in the inner ear," International Journal of Developmental Biology, vol. 51, no. 6-7, pp. 483-493, 2007.

[55] S. J. Jeon, M. Fujioka, S. C. Kim, and A. S. B. Edge, "Notch signaling alters sensory or neuronal cell fate specification of inner ear stem cells," Journal of Neuroscience, vol. 31, no. 23, pp. 8351-8358, 2011.

[56] S. K. Olsen, J. Y. H. Li, C. Bromleigh et al., "Structural basis by which alternative splicing modulates the organizer activity of FGF8 in the brain," Genes and Development, vol. 20, no. 2, pp. 185-198, 2006.

[57] K. Shim, G. Minowada, D. E. Coling, and G. R. Martin, "Sprouty2, a mouse deafness gene, regulates cell fate decisions in the auditory sensory epithelium by antagonizing FGF signaling," Developmental Cell, vol. 8, no. 4, pp. 553-564, 2005.

[58] M. C. Kelly and P. Chen, "Development of form and function in the mammalian cochlea," Current Opinion in Neurobiology, vol. 19, no. 4, pp. 395-401, 2009.

[59] M. Classon and N. Dyson, "p107 and p130: versatile proteins with interesting pockets," Experimental Cell Research, vol. 264, no. 1, pp. 135-147, 2001.

[60] J. M. Laakso, J. H. Lewis, H. Shuman, and E. M. Ostap, "Myosin I can act as a molecular force sensor," Science, vol. 321, no. 5885, pp. 133-136, 2008.

[61] D. P. Syamaladevi, J. A. Spudich, and R. Sowdhamini, "Structural and functional insights on the Myosin superfamily," Bioinformatics and Biology Insights, vol. 6, pp. 11-21, 2012.

[62] P. G. Gillespie and J. L. Cyr, "Myosin-1c, the hair cell's adaptation motor," Annual Review of Physiology, vol. 66, pp. 521-545, 2004.

[63] J. R. Holt, S. K. H. Gillespie, D. W. Provance et al., "A chemical-genetic strategy implicates myosin-1c in adaptation by hair cells," Cell, vol. 108, no. 3, pp. 371-381, 2002.

[64] S. P. Gubbels, D. W. Woessner, J. C. Mitchell, A. J. Ricci, and J. V. Brigande, "Functional auditory hair cells produced in the mammalian cochlea by in utero gene transfer," Nature, vol. 455, no. 7212, pp. 537-541, 2008.

[65] S. D. M. Brown, R. E. Hardisty-Hughes, and P. Mburu, "Quiet as a mouse: dissecting the molecular and genetic basis of hearing," Nature Reviews Genetics, vol. 9, no. 4, pp. 277290, 2008.

[66] N. A. Bermingham, B. A. Hassan, S. D. Price et al., "Math 1: an essential gene for the generation of inner ear hair cells," Science, vol. 284, no. 5421, pp. 1837-1841, 1999.

[67] K. Kawamoto, S. I. Ishimoto, R. Minoda, D. E. Brough, and Y. Raphael, "Math1 gene transfer generates new cochlear hair cells in mature guinea pigs in vivo," Journal of Neuroscience, vol. 23, no. 11, pp. 4395-4400, 2003.

[68] M. Izumikawa, S. A. Batts, T. Miyazawa, D. L. Swiderski, and Y. Raphael, "Response of the flat cochlear epithelium to forced expression of Atoh1," Hearing Research, vol. 240, no. 1-2, pp. 52-56, 2008.

[69] R. Minoda, M. Izumikawa, K. Kawamoto, H. Zhang, and Y. Raphael, "Manipulating cell cycle regulation in the mature cochlea," Hearing Research, vol. 232, no. 1-2, pp. 44-51, 2007.

[70] I. Breuskin, M. Bodson, N. Thelen et al., "Strategies to regenerate hair cells: identification of progenitors and critical genes," Hearing Research, vol. 236, no. 1-2, pp. 1-10, 2008.

[71] H. Li, H. Liu, and S. Heller, "Pluripotent stem cells from the adult mouse inner ear," Nature Medicine, vol. 9, no. 10, pp. 1293-1299, 2003.

[72] J. S. Stone and D. A. Cotanche, "Hair cell regeneration in the avian auditory epithelium," International Journal of Developmental Biology, vol. 51, no. 6-7, pp. 633-647, 2007.

[73] P. P. Hernández, F. A. Olivari, A. F. Sarrazin, P. C. Sandoval, and M. L. Allende, "Regeneration in zebrafish lateral line neuromasts: expression of the neural progenitor cell marker Sox 2 and proliferation-dependent and -independent mechanisms of hair cell renewal," Developmental Neurobiology, vol. 67, no. 5, pp. 637-654, 2007. 
[74] R. R. Taylor and A. Forge, "Hair cell regeneration in sensory epithelia from the inner ear of a urodele amphibian," Journal of Comparative Neurology, vol. 484, no. 1, pp. 105-120, 2005.

[75] A. Forge, L. Li, and G. Nevill, "Hair cell recovery in the vestibular sensory epithelia of mature guinea pigs," The Journal of Comparative Neurology, vol. 397, no. 1, pp. 69-88, 1998.

[76] L. Lin and A. Forge, "Morphological evidence for supporting cell to hair cell conversion in the mammalian utricular macula," International Journal of Developmental Neuroscience, vol. 15, no. 4-5, pp. 433-446, 1997.

[77] P. C. Roehm and M. R. Hansen, "Strategies to preserve or regenerate spiral ganglion neurons," Current Opinion in Otolaryngology and Head and Neck Surgery, vol. 13, no. 5, pp. 294-300, 2005.

[78] N. A. Hardie and R. K. Shepherd, "Sensorineural hearing loss during development: morphological and physiological response of the cochlea and auditory brainstem," Hearing Research, vol. 128, no. 1-2, pp. 147-165, 1999.

[79] J. Ylikoski, U. Pirvola, M. Moshnyakov, J. Palgi, U. Arumae, and M. Saarma, "Expression patterns of neurotrophin and their receptor mRNAs in the rat inner ear," Hearing Research, vol. 65, no. 1-2, pp. 69-78, 1993.

[80] K. Stankovic, C. Rio, A. Xia et al., "Survival of adult spiral ganglion neurons requires erbB receptor signaling in the inner ear," Journal of Neuroscience, vol. 24, no. 40, pp. 86518661, 2004.

[81] A. K. Wise, R. Richardson, J. Hardman, G. Clark, and S. O'Leary, "Resprouting and survival of guinea pig cochlear neurons in response to the administration of the neurotrophins brain-derived neurotrophic factor and neurotrophin-3," Journal of Comparative Neurology, vol. 487, no. 2, pp. 147-165, 2005.

[82] M. J. H. Agterberg, H. Versnel, J. C. M. J. de Groot, G. F. Smoorenburg, F. W. J. Albers, and S. F. L. Klis, "Morphological changes in spiral ganglion cells after intracochlear application of brain-derived neurotrophic factor in deafened guinea pigs," Hearing Research, vol. 244, no. 1-2, pp. 25-34, 2008.

[83] S. J. Wang, M. Furusho, C. D’Sa et al., "Inactivation of fibroblast growth factor receptor signaling in myelinating glial cells results in significant loss of adult spiral ganglion neurons accompanied by age-related hearing impairment," Journal of Neuroscience Research, vol. 87, no. 15, pp. 3428-3437, 2009.

[84] D. Wei, Z. Jin, L. Järlebark, E. Scarfone, and M. Ulfendahl, "Survival, synaptogenesis, and regeneration of adult mouse spiral ganglion neurons in vitro," Developmental Neurobiology, vol. 67, no. 1, pp. 108-122, 2007.

[85] R. K. Shepherd, A. Coco, S. B. Epp, and J. M. Crook, "Chronic depolarization enhances the trophic effects of brain-derived neurotrophic factor in rescuing auditory neurons following a sensorineural hearing loss," Journal of Comparative Neurology, vol. 486, no. 2, pp. 145-158, 2005.

[86] A. K. Wise, T. Tu, P. J. Atkinson et al., "The effect of deafness duration on neurotrophin gene therapy for spiral ganglion neuron protection," Hearing Research, vol. 278, no. 1-2, pp. 69-76, 2011.

[87] M. Sugawara, G. Corfas, and M. C. Liberman, "Influence of supporting cells on neuronal degeneration after hair cell loss," Journal of the Association for Research in Otolaryngology, vol. 6, no. 2, pp. 136-147, 2005.
[88] H. Li, G. Roblin, H. Liu, and S. Heller, "Generation of hair cells by stepwise differentiation of embryonic stem cells," Proceedings of the National Academy of Sciences of the United States of America, vol. 100, no. 23, pp. 13495-13500, 2003.

[89] Y. Naito, T. Nakamura, T. Nakagawa et al., "Transplantation of bone marrow stromal cells into the cochlea of chinchillas," NeuroReport, vol. 15, no. 1, pp. 1-4, 2004.

[90] Z. Hu, M. Ulfendahl, and N. P. Olivius, "Survival of neuronal tissue following xenograft implantation into the adult rat inner ear," Experimental Neurology, vol. 185, no. 1, pp. 7-14, 2004.

[91] P. Olivius, L. Alexandrov, J. Miller, M. Ulfendahl, D. BaggerSjöbäck, and E. N. Kozlova, "Allografted fetal dorsal root ganglion neuronal survival in the guinea pig cochlea," Brain Research, vol. 979, no. 1-2, pp. 1-6, 2003.

[92] Z. Hu, M. Ulfendahl, D. M. Prieskorn, P. Olivius, and J. M. Miller, "Functional evaluation of a cell replacement therapy in the inner ear," Otology \& Neurotology, vol. 30, no. 4, pp. 551-558, 2009.

[93] C. Regala, M. Duan, J. Zou, M. Salminen, and P. Olivius, "Xenografted fetal dorsal root ganglion, embryonic stem cell and adult neural stem cell survival following implantation into the adult vestibulocochlear nerve," Experimental Neurology, vol. 193, no. 2, pp. 326-333, 2005.

[94] W. Chen, N. Jongkamonwiwat, L. Abbas et al., "Restoration of auditory evoked responses by human ES-cell-derived otic progenitors," Nature, vol. 490, no. 7419, pp. 278-282, 2012.

[95] P. V. Vlastarakos, T. P. Nikolopoulos, E. Tavoulari, G. Papacharalambous, A. Tzagaroulakis, and S. Dazert, "Sensory cell regeneration and stem cells: what we have already achieved in the management of deafness," Otology and Neurotology, vol. 29, no. 6, pp. 758-768, 2008.

[96] G. G. Kingma, J. M. Miller, and M. W. Myers, "Chronic drug infusion into the scale tympani of the guinea pig cochlea," Journal of Neuroscience Methods, vol. 45, no. 1-2, pp. 127134, 1992.

[97] J. N. Brown, J. M. Miller, R. A. Altschuler, and A. L. Nuttall, "Osmotic pump implant for chronic infusion of drugs into the inner ear," Hearing Research, vol. 70, no. 2, pp. 167-172, 1993.

[98] M. N. Rivolta, "Stem cells and cell lines from the human auditory organ: applications, hurdles and bottlenecks in the development of regenerative therapies for deafness," Drug Discovery Today, vol. 15, no. 7-8, pp. 283-286, 2010.

[99] S. B. Shibata, G. Di Pasquale, S. R. Cortez, J. A. Chiorini, and Y. Raphael, "Gene transfer using bovine adeno-associated virus in the guinea pig cochlea," Gene Therapy, vol. 16, no. 8, pp. 990-997, 2009.

[100] G. Crispino, G. Di Pasquale, P. Scimemi et al., "BAAV mediated GJB2 gene transfer restores gap junction coupling in cochlear organotypic cultures from deaf Cx26Sox10Cre mice," PLoS ONE, vol. 6, no. 8, Article ID e23279, 2011.

[101] J. Wu, B. Liu, J. Fan, Q. Zhu, and J. Wu, "Study of protective effect on rat cochlear spiral ganglion after blast exposure by adenovirus-mediated human $\beta$-nerve growth factor gene," American Journal of Otolaryngology, vol. 32, no. 1, pp. 8-12, 2011.

[102] W. Zhang, Y. Zhang, M. Lobler et al., "Nuclear entry of hyperbranched polylysine nanoparticles into cochlear cells," International Journal of Nanomedicine, vol. 6, pp. 535-546, 2011. 
[103] S. Roy, A. H. Johnston, T. A. Newman et al., "Cell-specific targeting in the mouse inner ear using nanoparticles conjugated with a neurotrophin-derived peptide ligand: potential tool for drug delivery," International Journal of Pharmaceutics, vol. 390, no. 2, pp. 214-224, 2010.

[104] D. P. Paulson, W. Abuzeid, H. Jiang, T. Oe, B. W. O’Malley, and $\mathrm{D}$. Li, "A novel controlled local drug delivery system for inner ear disease," Laryngoscope, vol. 118, no. 4, pp. 706-711, 2008.

[105] D. Buckiova, S. Ranjan, T. A. Newman et al., "Minimally invasive drug delivery to the cochlea through application of nanoparticles to the round window membrane," Nanomedicine, vol. 7, no. 9, pp. 1339-1354, 2012.

[106] Z. A. Mood and S. J. Daniel, "Use of a microendoscope for transtympanic drug delivery to the round window membrane in chinchillas," Otology \& Neurotology, vol. 33, no. 8, pp. 1292-1296, 2012.

[107] A. Bohl, H. W. Rohm, P. Ceschi et al., "Development of a specially tailored local drug delivery system for the prevention of fibrosis after insertion of cochlear implants into the inner ear," Journal of Materials Science, vol. 23, no. 9, pp. 2151-2162, 2012.

[108] E. E. L. Pararas, Z. Chen, J. Fiering et al., "Kinetics of reciprocating drug delivery to the inner ear," Journal of Controlled Release, vol. 152, no. 2, pp. 270-277, 2011. 

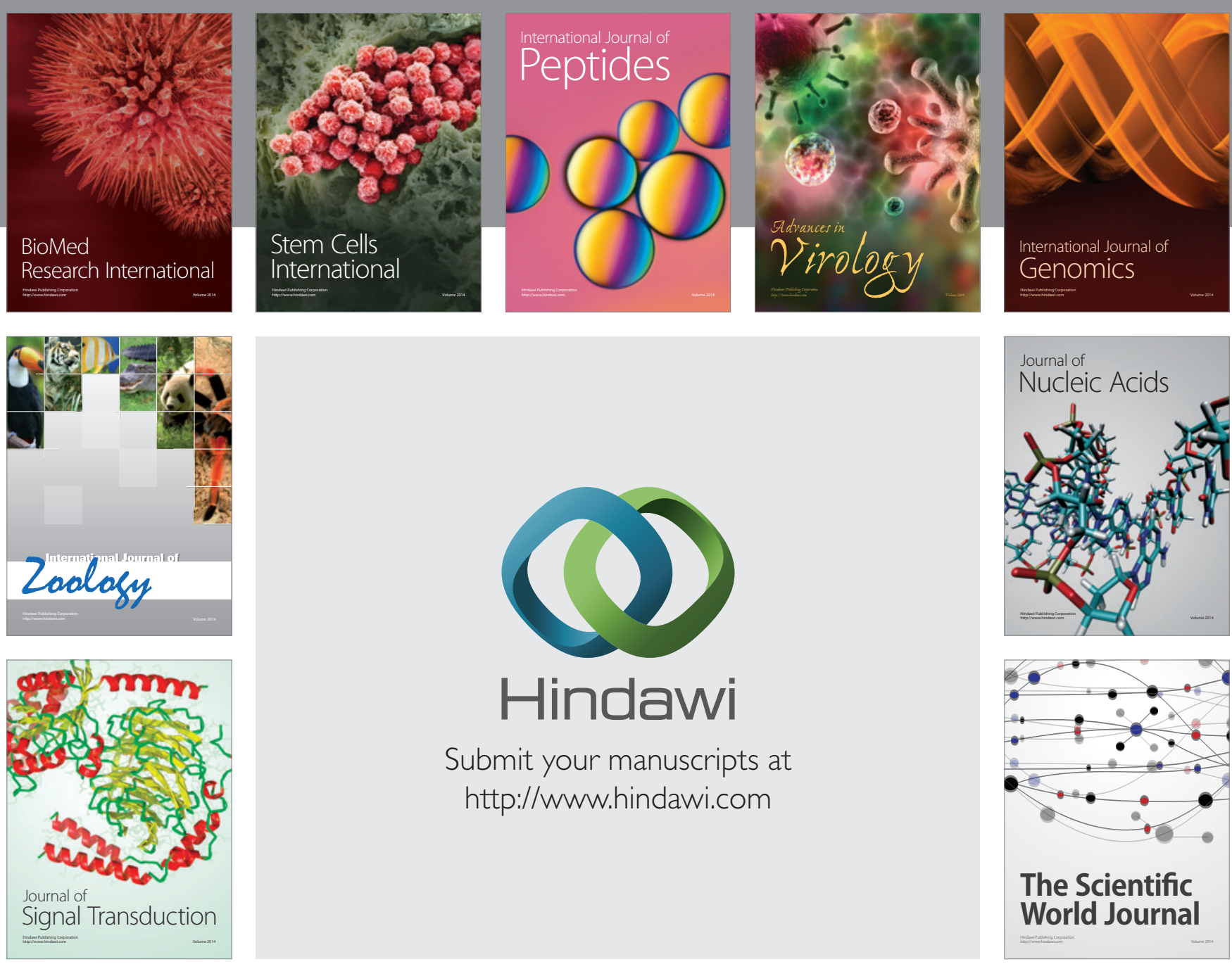

Submit your manuscripts at

http://www.hindawi.com
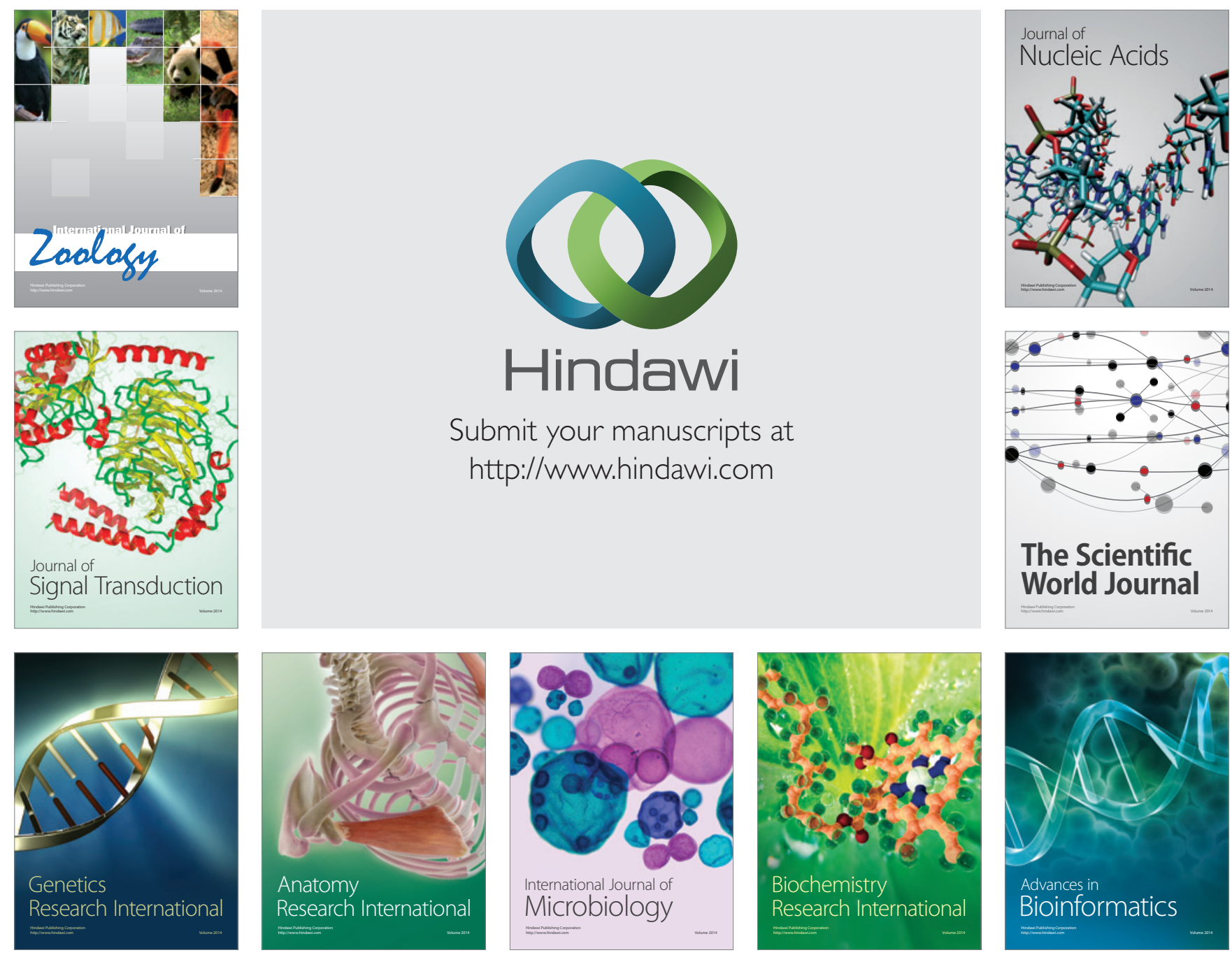

The Scientific World Journal
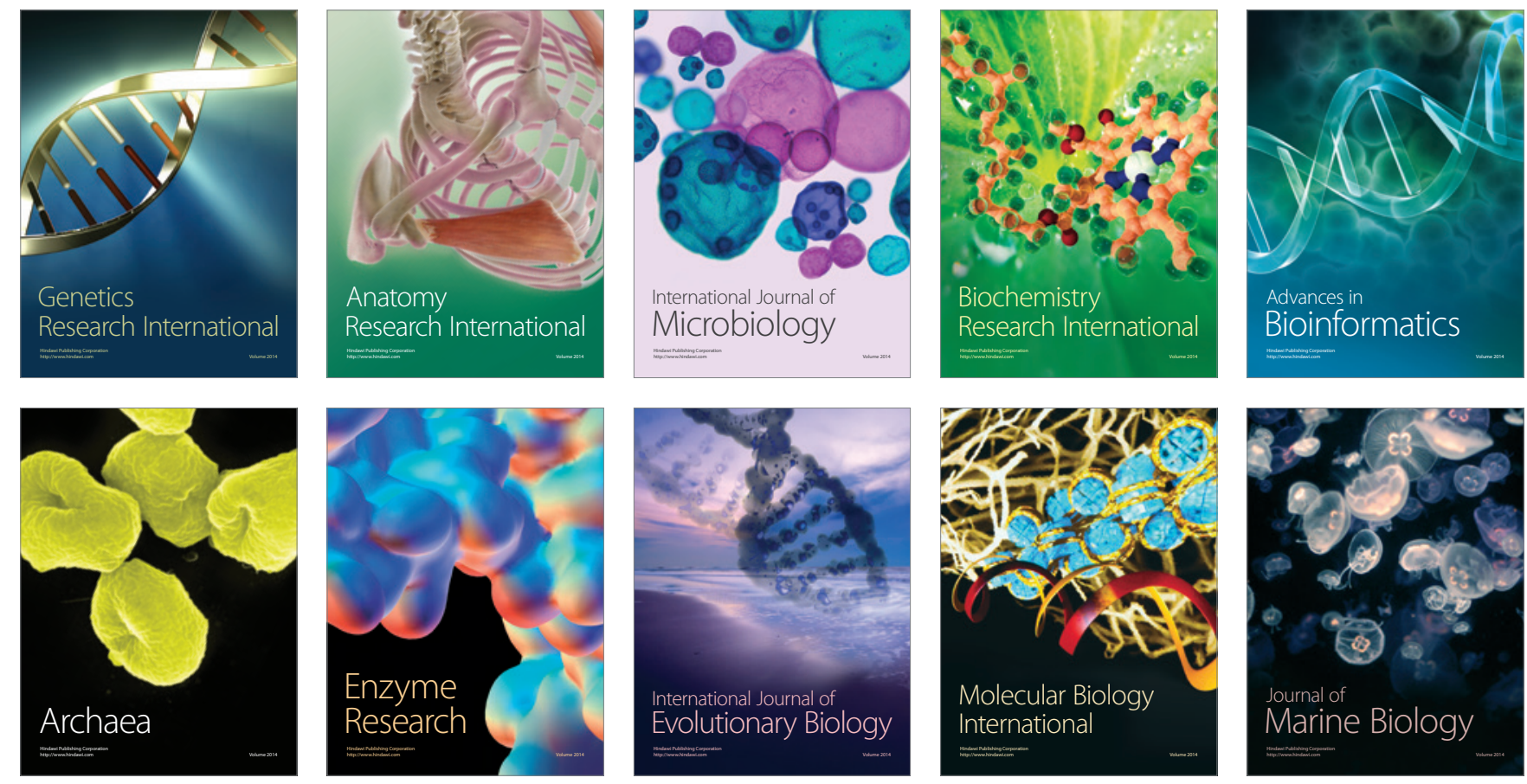